\title{
PERILAKU INFORMASI PARA PENGGALI EMAS TRADISIONAL (GURANDIL) DALAM MELAKUKAN KEGIATAN EKSPLORASI DAN PENGOLAHAN TAMBANG EMAS
}

\author{
Tine Silvana ${ }^{1}$, Yunus Winoto ${ }^{2}$ \\ ${ }^{1,2}$ Program Studi Ilmu Perpustakaan Universitas Padjadjaran \\ 1'tine.silvana@unpad.ac.id, ${ }^{2}$ yunus.winoto@unpad.ac.id
}

\begin{abstract}
In this study researchers are interested to examine how the behavior of information among the traditional gold mining or "gurandil" in the know and perform a search for information about the new gold mining location area that is done by the group pengalian sedan other gold. The method used in this research is a qualitative method with fenomenologi approach. In the use of the channel information that is done by the gold mining Districts Cineam Tasikmalaya District to obtain information about the development of gold digging other groups they use the channel in the form of media phone or HP to ask the condition and development of other gold digging groups either do pengalian saloon in other areas or on the new mining come from other areas. In addition, the probing this gold also usually using traditional channels, means the pengali gold that is located in the area of the Sub-district Cineam venom orally ask probing the gold that chance arrived or on the family/kin about the development of gold digging in other areas.
\end{abstract}

Keywords: Information Behavior, Traditional Gold Mining, Gold Mining Processing

ABSTRAK - Dalam penelitian ini peneliti tertarik untuk mengkaji bagaimana perilaku informasi di kalangan para penggali emas tradisional atau "gurandil" dalam mengetahui dan melakukan pencarian informasi mengenai daerah lokasi penggali emas baru yang sedan dilakukan oleh kelompok pengalian emas lainnya. Metode yang digunakan dalam penelitian ini adalah metode kualitatif dengan pendekatan fenomenologi. Dalam penggunaan saluran informasi yang dilakukan para penggali emas di Wilayah Kecamatan Cineam Kabupaten Tasikmalaya dalam memperoleh informasi tentang perkembangan penggalian emas kelompok lainnya mereka menggunakan saluran yang berupa media telepon atau HP untuk menanyakan kondisi dan perkembangan kelompok penggalian emas lainnya baik yang sedan melakukan pengalian di daerah lain atau pada para penggali yang baru datang dari daerah lain. Selain itu, para penggali emas ini juga biasanya mengunakan saluran secara tradisional, artinya para pengali emas yang sedang berada di wilayah Kecamatan Cineam bisanya secara lisan menanyakan kepada para penggali emas yang kebetulan baru datang atau pada keluarga /kerabatnya mengenai perkembangan penggalian emas di daerah lainnya.

Kata kunci: Perilaku Informasi, Penggali Emas Tradisional, Pengolahan Tambang emas

\section{PENDAHULUAN}

Kabupaten Tasikmalaya sebagai salah satu kabupaten yang ada di wilayah selatan Jawa Barat mempunyai potensi sumber daya alam yang sangat menjanjikan khususnya di bidang pertambangan, bahkan berdasarkan data yang diperoleh dari Dinas Pertambangan dan Energi Kabupaten Tasikmalaya disebutkan bahwa terdapat sekitar 35 bahan tambang yang tersebar di beberapa wilayah di Kabupaten Tasikmalaya. Salah satu kecamatan yang cukup terkenal dengan daerah pertambangan emas adalah Kecamatan Cineam, (Sumber: Dinas Pertambangan Dan Energi Kab. Tasikmalaya, 2013).

Potensi pertambangan emas rakyat yang ada

di Kecamatan Cineam adalah merupakan 
pertambangan emas yang cukup lama yang terdapat di Kabupaten Tasikmalaya dan sampai saat ini pertambangan emas ini masih berjalan dan dikuasai masyarakat setempat. Dalam melakukan kegiatan dan pengolahan tambang emas di Kecamatan Cineam ini masih dilakukan secara tradisional yakni dengan cara menggali lubang secara vertikal dengan kedalaman yang bervariasi untuk mengikuti urat emas yang ada. Untuk kedalaman vertikalnya saja bisa mencapai $30 \mathrm{~m}$ sampai dengan 40 M. Untuk selanjutnya penambang terus mengikuti urat emas sampai beberapa puluh meter dari penggalian vertikal tersebut.

Berbicara lebih jauh tentang penggalian emas tradisional, khususnya yang ada di Kecamatan Cineam apabila dilihat dari resiko bahayanya, sebenarnya sangat berbahaya sekali selain akan mengancam kesematalan jiwa para penggalinya, karena hampir semua para penggali emas tradisional tidak dilengkapi peralatan yang memadai untuk aspek keselamatan. Oleh karena itu tidak heran mampir setiap tahun terjadi kecelakaan yang dialami para penggali pada saat penggalian emas di wilayah Kecamatan Cineam. Pada akhir bulan Juli 2014 terdapat 4 orang dari 8 orang penggali emas di Kecamatan Cineam meregang nyawa karena tertimbun pada waktu melakukan penggalian, (Sumber: Pikiran Rakyat, 2014).

Selain bahaya untuk para penggali, bahaya lain yang tidak kalah besarnya adalah bahaya terhadap keselamatan lingkungan. Adapun bahaya pertama adalah dari tumpukan tanah pada saat penggalian atau masyarakat Kecamatan Cineam menyebutnya gamping yang dibuang begitu saja disekitar tempat penggalian, sehingga semakin dalam proses penggalian lubang emas, maka tumpukan tanah akan semakin banyak. Dengan kondisi ini akan rawan menimbulkan bahaya longsor, karena biasanya tempat pengalian emas berada di daerah perbukitan. Sedangkan bahaya yang kedua, adalah pada saat proses pengolahannya. Untuk pengolahan emas yang ada di Kecamatan Cineam menggunakan proses amalgama yakni proses pengikatan emas dengan menggunakan merkuri (Hg). Sebagaimana kita ketahui merkuri atau air raksa adalah merupakan salah satu unsur logam berat yang akan membahayakan organ tubuh manusia seperti otak, paru-paru, system syarat pusat serta ginjal. Sebagai gambaran di wilayah tempat penggalian emas yang ada di empat Desa seperti desa Cikondang, Pasirmukti, Desa Citambal dan Desa Cisarua serta daerah penambangan emas yang ada di Kecamatan Karangjaya terdapat sekitar 12 sungai yang sebagian di sekitar hulunya dipakai tempat pengolahan dan pembuangan limbah pengolahan emas. Oleh karena demikian bahaya untuk lingkungan dan kesehatan manusia disekitar tempat penambanan emas ini harus menjadi perhatian semua pihak.

Apabila memperhatikan proses penambangan emas yang dilakukan secara tradisional di Wilayah Kecamatan Cineam ini, sebenarnya sangat tidak sepadan dengan bahaya yang ditimbulkan baik pad saat melakukan penggalian maupun pada saat proses pengolahannya. Menurut hasil penelitian yang dilakukan oleh Denni Widhiyatna (2005) dari Subdit Konservasi Dinas Pertambangan dan Energi Kabupaten Tasikmalaya, menyatakan bahwa proses pengolahan 
emas dengan cara amalgamasi di Kecamatan Cineam telah menyebabkan terjadinya penurunan kualitas air sungai di lingkungan sekitarnya akibat pembuangan limbah hasil pengolahan. Adapun gejala ini dapat dilihat dengan berubahnya warna air sungai menjadi keruh keabuan, terjadinya sedimentasi, berubahnya derajat keasaman air serta teredapkannya butir-butir merkuri di sungaisungai tertentu akibat pembuatan tailing atau limbah padat dari gelundung.

Di wilayah Kecamatan Cineam selain terdapat lokasi penambangan emas rakyat, juga terdapat kelompok para penggali emas tradisional atau dikenal dengan sebutan "Gurandil". Kelompok penggali emas tradisional ini sebenarnya terdiri dari para pemilik modal, buruh gali serta buruh angkut tanah hasil penggalian ke tempat pengolahan emas. Pada umumnya yang menjadi pemilik modal adalah mereka yang sudah turun menurun sebagai penggali emas dan mempunyai banyak penggalaman dalam hal ihwal penggalian emas serta mereka mempunyai modal dan perlengkapan untuk penggalian dan pengolahan emas. Sedangkan para buruh gali maupun buruh angkut biasanya mereka yang tidak memiliki modal atau hanya pekerjaan sambilan karena tidak memiliki kerja yang tetap.

Dalam mencari lokasi tempat penambangan emas para penggali emas, khususnya para pemilik modal biasanya melakukan penjajagan ke beberapa wilayah dan tidak terbatas di wilayah Jawa Barat saja tetapi menjelajahi beberapa provinsi lainnya mulai dari Irian Jaya, Maluku, NTB, Jambi, Padang, Medan bahkan sampai ke Provinsi Aceh. Peran seorang penggali emas yang merupakan pemodal adalah melakukan perintisan daerah-daerah yang akan menjadi lokasi penggalian emas. Biasanya mereka melakukan survey ke beberapa provinsi untuk mencari daerah yang akan menjadi tempat penggalian emas baru.

Dilihat dari sisi pendidikannya para penambang emas ini, pada umumnya tidak memiliki pendidikan yang khusus tentang penambangan emas. Mereka berangkat dari pengalaman yang telah digelutinya selama ini, sehingga mereka bisa menentukan lokasi atau daerah mana yang memiliki kandungan emas atau tidak. Dalam melakukan penjajagan ke suatu daerah yang mengandung emas, para penggali emas (pemodal) ini bersama-sama atau sendirisendiri melakukan perintisan dengan cara menelusuri daerah-daerah terutama pinggiran sungai untuk mengamati apakah di daerah tersebut terdapat kandungan emas. Apabila diyakini di wilayah tersebut mengandung emas, maka para penggali (pemodal) ini kembali dulu ke daerahnya atau mengontak langsun anak buahnya untuk datang ke lokasi penggalian baru.

Apabila kegiatan perintisan dan penggalian emas tersebut berhasil, akan menjadi informasi baru bagi para penggali emas lainnya, tidak hanya bagi para penggali emas yang ada di daerahnya, akan tetapi bagi para penggali emas yang tinggal di daerah lainnya. Selanjutnya para penggali emas lainnya dari berbagai daerah secara berkelompok dan berduyun-duyun menuju lokasi penambangan emas baru. Peristiwa terjadi secara berulang-ulang misalnya mulai dari penemuan penggalian emas di Irian Jaya, Maluku, NTB, Medan sampai dengan penggalian emas di Padang Sumatera Barat.

Dalam kontek penelitian ini peneliti tertarik untuk mengkaji bagaimana perilaku informasi di 
kalangan para penggali emas tradisional atau "gurandil" dalam mengetahui dan melakukan pencarian informasi mengenai daerah lokasi penggali emas baru yang sedan dilakukan oleh kelompok pengalian emas lainnya. Adapun mengenai pengertian perilaku informasi (information behavior) itu sendiri menurut Wilson (2000) adalah merupakan keseluruhan perilaku manusia yang berkaitan dengan sumber dan saluran informasi termasuk dalam hal ini pencarian dan penggunaan informasi baik secara aktif maupun secara pasif.

Berangkat dari dari latar belakang masalah tersebut di atas, maka dapat dirumuskan masalah sebagai berikut: "Bagaimana Perilaku Informasi Para Penggali Emas Tradisional (Gurandil) Dalam Memperoleh Informasi Tentang Penambangan Emas Baru?".

Selanjutnya dari perumusan tersebut, penelitian ini lebih lebih difokuskan pada aspek sebagai berikut:

1. Bagaimana aspek kehidupan para penggali emas tradisional (gurandil) yang ada di Kecamatan Cineam kabupaten Tasikmalaya dalam konteks sebagai pencari dan pengguna informasi.

2. Bagaimana pengalaman para penggali emas tradisional (gurandil) dalam menggunakan saluran informasi untuk memperoleh informasi tentang daerah penambagangan emas.

3. Bagaimana pengalaman para penggali emas tradisional (gurandil) dalam menggunakan berbagai sumber daya informasi untuk memperoleh informasi tentang daerah penambangan emas.
Mengenai tujuan dari penelitian ini adalah sebagai berikut:

a) Untuk mengetahui kehidupan para penggali emas tradisional (gurandil) yang ada di Kecamatan Cineam kabupaten Tasikmalaya sebagai pencari informasi?

b) Untuk mengetahui bagaimana pengalaman para penggali emas tradisional (gurandil) dalam menggunakan saluran informasi untuk menemukan daerah penambagangan emas?

c) Untuk mengetahui bagaimana pengalaman para penggali emas tradisional (gurandil) dalam menggunakan berbagai sumber daya informasi untuk mencari informasi daerah penambangan emas?

Manfaat yang diharapkan dari kegiatan penelitian ini yakni sebagai berikut: Dari hasil penelitian ini diharapkan dapat memberikan pengalaman ilmiah bagi penulis dalam mengkaji tentang perilaku informasi para penggali emas tradisional dengan mengunakan pendekatan kualitatif dengan jenis penelitian fenomenologi. Sedangkan manfaat paktis dari hasil penelitian ini yaitu, dari hasil penelitian ini diharapkan dapat memberikan masukan bagi Pemerintah Desa Ciondang dan desa Pasirmukti, Pemerintah Kecamatan Cineam maupun Dinas Pertambangan dan Energi Kabupaten Tasikmalaya mengenai pola perilaku informasi di kalanan para para penggali emas yang ada di wilayah Kecamatan Cineam. 


\section{TINJAUAN PUSTAKA}

Sebagaimana yang telah dipaparkan sebelumnya pengertian perilaku informasi (information behavior) adalah merupakan keseluruhan perilaku manusia berkaitan dengan sumber dan saluran informasi, termasuk dalam hal ini pencarian dan penggunaan informasi baik secara aktif maupun pasif. Perilaku dan penggunaan merupakan suatu kegiatan yang tidak bisa dipisahkan dari kehidupan manusia seharihari. Begitu juga perilaku mencari dan menggunakan informasi adalah merupakan bagian tetap dalam kehidupan manusia (Johnstone dan Tate, 2004).

Lebih jauh tentang perilaku informasi, dalam penelitian ini peneliti mencoba menggunakan teori perilaku dari Wilson (2000) untuk menjelaskan masalah yang sedang dikaji. Menurut Wilson ada tiga hal yang berkaitan dengan perilaku informasi yakni aspek kehidupan pencari informasi, saluran serta sumber informasi yang digunakan. Adapun aspek kehidupan pencari informasi ini yakni yang menyangkut pekerjaan atau mata pencaharian seseorang dapat mendorong melakukan proses pencarian dan penggunaan informasi.

Secara sederhana Wilson, mengambarkan proses perilaku informasi yang meliputi pencarian dan penggunaan informasi sebagai berikut:

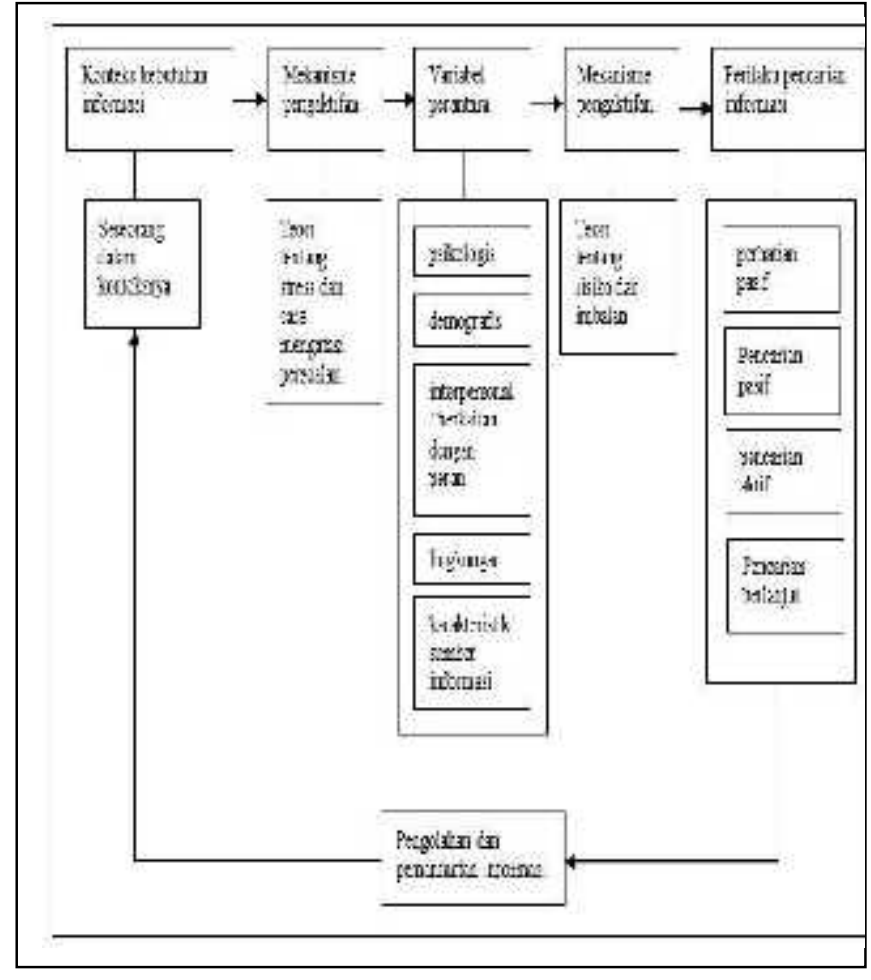

Gambar 1 Pencarian dan Penggunaan Infromasi

Menurut Wilson (2000) suatu kebutuhan akan informasi tidak serta merta akan berubah menjadi sebuah perilaku mencari informasi. Namun harus dipicu terlebih dahulu oleh pemahaman seseorang tentang tekanan dan persoalan dalam hidupnya. Misalnya dalam konteks para penggali emas tradisional kebutuhan informasi tentang lokasi penambangan baru, akan menjadi sebuah perilaku pencarian informasi jika mereka terdorong oleh keadaan dan kesulitan kehidupan ekonomi di daerahnya, sehingga perlu mencari tahu tentang bagaimana perkembangan para pencari emas kelompok lainnya serta daerah mana yang sedang menjadi tujuan mereka.Selain tiu juga faktor lain yang mempengaruhi dalam pencarian informasi ini yaitu faktor psikologis, demografis, peran seorang di dalam masyarakat, misalnya seorang penggali emas yang merupakan pemilik modal dan buruh akan berbeda dalam 
perilaku mencari informasi serta fakor lingkungan dan karakteristik sumber informasi yang digunakan.

Hal ini yang mempengaruhi pencarian informasi adalah pandangan seseorang tentang resiko dan imbalan yang akan dihadapi jika ia benar-benar melakukan pencarian informasi. Misalnya seorang penggali emas yang akan mencari informasi tentang perkembangan pencarian emas kelompok lain, akan mendapat informasi tentang kegiatan yang dilakukan kelompok lain serta keuntungan yang telah diperoleh kelompok lain dalam melakukan penggalian emas selama ini. Selanjutnya pada akhirnya perilaku akan dilakukan baik berupa perhatian pasif sampai dengan menyakan secara langsung pada kelompok atau orang yang sedang menggali emas atau baru pulang dari lokasi penggalian emas baru.

Berdasarkan model perilaku informasi di atas, maka dalam konteks penelitian yang kami lakukan dapat dikemukakan bahwa perilaku pencarian informasi di kalangan para penggali emas di kecamatan Cineam muncul karena adanya tekanan yang berkaitan dengan kehidupan ekonomi mereka sehari-hari sehingga mendorong untuk mencari informasi tentang perkembangan penggalian emas kelompok lainnya. Informasi ini selanjutnya mereka gunakan untuk memutuskan kelompok mereka untuk turut bergabung dalam penggalian emas di lokasi baru yang sedang dilakukan oleh kelompok pengali emas lainnya.

\section{METODE PENLITIAN}

Metode yang digunakan dalam penelitian ini adalah metode kualitatif dengan pendekatan fenomenologi. Littlejohn (1999) mendefinisikan fenomenologi sebagai studi tentang pengalaman yang datang dari kesadaran atau cara kita memahami sesuatu dengan secara sadar mengalami sesuatu tersebut. Sedangkan menurut Hegel (dalam Moustakas 1994, 26) fenomenologi mengacu pada pengalaman sebagaimana yang muncul pada kesadaran, lebih lanjut ia menjelaskan fenomenologi adalah ilmu menggambarkan apa yang seseorang terima, rasakan dan ketahui di dalam kesadaran langsungnya dan pengalamannya. Dan apa yang muncul dari kesadaran itulah yang disebut sebagai fenomena.

Prinsip fenomenologi berkenaan dengan pemahaman tentang bagaimana keseharian, dunia intersubyektif (dunia kehidupan) atau juga disebut Lebenswelt terbentuk. Fenomenologi bertujuan mengetahui bagaimana kita menginter-pretasikan tindakan sosial kita dan orang lain sebagai sebuah yang bermakna (dimaknai) dan untuk merekonstruksi kembali turunan makna (makna yang digunakan saat berikutnya) dari tindakan yang bermakna pada komunikasi intersubjektif individu dalam dunia kehidupan sosial.

\section{HASIL PENELITIAN}

Apabila merujuk pada pendapat yang dikemukakan Wilson (2000) perilaku informasi terkait dengan aspek kehidupan orang sebagai pencari informasinya. Hal ini dikarenakan perilaku informasi terkait dengan kebutuhan informasi orang tersebut. Berkaitan dengan kehidupan para pencari emas yang ada di Kecamatan Cineam, jka dilihat aspek pendidikannya hampir sebagian besar para 
penggali emas tradisional rata-rata berpendidikan $\mathrm{SD} /$ sederajat dan hanya beberapa orang saja yang tamat SLTP/MTs dan SLTA/MA.

Kemudian jika dilihat dari pekerjaannya hampir sebagian besar penggali emas tidak memiliki perkerjaan yang tetap atau serabutan. Hal ini terutama untuk para penggali yang merupakan tenaga buruh. Sedangkan untuk para penggali yang merupakan pemodal atau yang menjadi penyandang dana dan fasilitas biasanya orang yan kedudukannya cukup mapan di daerahnya. Selain itu juga para pemodal atau penyandang dana ini pada umumnya merupakan suatu keluarga yang telah lama dan secara turun menurun mengeluti masalah penggalian tambang emas.

Kondisi alam tempat tinggal para responden yakni di daerah Cikondang dan Desa Pasirmukti adalah merupakan daerah pegunungan yang tanahnya kurang subur dan hanya ditanami tanaman keras seperti kayu sengon dan daerah pesawahan tadah hujan.Selain itu juga pada uumnya dari penggali emas yan merupakan buruh, tidak memiliki tanah pesawahan maupun kebun yang cukup untuk bertani.

Dalam konteks perilaku informasi yang terjadi di lingkungan para pengali emas tradisional di Kecamatan Cineam, faktor kebutuhan informasi untuk mengetahui bagaimana perkembangan para pencarian emas kelompok lain yang sedang ada di daerah serta bagaimana keuntungan yang mereka peroleh ditambah tekanan kehidupan ekonomi, pekerjaan para penggali yang pada umumnya tidak menetap serta tidak memilikinya keahlian lain telah mendorong mereka untuk melakukan pencarian informasi. Dalam melakukan pencarian informasi ini para penggali emas juga mengharapkan adanya informasi yang memuaskan tentang perkembangan penggalian emas di daerah lain, sehingga kelompok mereka dapat mengikuti jejak para penggali emas lainnya.

Aspek kedua dalam perilaku informasi seseorang berkaitan dengan saluran atau system informasi yang digunakan. Dalam penggunaan saluran informasi yang dilakukan para penggali emas di Wilayah Kecamatan Cineam Kabupaten Tasikmalaya dalam memperoleh informasi tentang perkembangan penggalian emas kelompok lainnya mereka menggunakan saluran yang berupa media telepon atau HP untuk menanyakan kondisi dan perkembangan kelompok penggalian emas lainnya baik yang sedan melakukan pengalian di daerah lain atau pada para penggali yang baru datang dari daerah lain. Selain menggunakan saluran atau system informasi yang bermedia seperti media telepon atau HP, para penggali emas ini juga biasanya mengunakan saluran secara tradisional, artinya para pengali emas yang sedang berada di wilayah Kecamatan Cineam bisanya secara lisan menanyakan kepada para penggali emas yang kebetulan baru datang atau pada keluarga/kerabatnya mengenai perkembangan penggalian emas di daerah lainnya.

Mengenai sumber daya informasi yan digunakan para penggali emas tradisional yang tinggal di kecamatan Cineam dalam mencari perkembangan penggalian emas yang sedang terjadi di daerah lain, sumber daya informasi yang digunakan berupa manusia baik itu pelaku yakni para penggali emasnya, maupun keluarga atau kerabatnya. 


\section{SIMPULAN}

1. Dilihat dari aspek kehidupan para pencari emas yang ada di Kecamatan Cineam, jka dilihat aspek pendidikannya hampir sebagian besar para penggali emas tradisional rata-rata berpendidikan $\mathrm{SD} /$ sederajat dan hanya beberapa orang saja yang tamat SLTP/MTs dan SLTA/MA; dari pekerjaan dan keterampilan yang dimiliki sebagian besar mereka tidak memiliki perkerjaan yang tetap atau serabutan dan tidak memiliki keterampilan khusus. Dari sisi kondisi alam Desa Cikondang dan Desa Pasirmukti adalah merupakan daerah pegunungan yang tanahnya kurang subur dan hanya ditanami tanaman keras seperti kayu sengon dan daerah pesawahan tadah hujan. Selain itu juga para penggali emas ini merupakan buruh yang tidak memiliki tanah pesawahan maupun kebun yang cukup untuk bertani. Oleh karena demikian dengan kondisi seperti ini akan mendorong mereka untuk melakukan pencarian informasi untuk mengetahui perkembangan para penggali emas kelompok lain yang sedang ada di daerah lain.

2. Mengenai penggunaan saluran atau system informasi, diketahui bahwa dalam melakukan pencarian informasi saluran informasi yang digunakan yaitu berupa media telepon atau HP untuk menanyakan kondisi dan perkembangan kelompok penggali emas lainnya baik yang sedang melakukan pengalian di daerah lain atau pada para penggali yang baru datang dari daerah lain. Selain menggunakan saluran atau system informasi yang bermedia seperti media telepon atau HP, saluran informasi lain yang digunakan adalah secara lisan yaitu dengan menanyakan kepada para penggali emas yang kebetulan baru datang atau pada keluarga/ kerabatnya mengenai perkembangan penggalian emas di daerah lainnya.

3. Sumber daya informasi yan digunakan para penggali emas tradisional yang tinggal di kecamatan Cineam dalam mencari perkembangan penggalian emas yang sedang terjadi di daerah lain, adalah sumber daya informasi yang berupa manusia baik itu pelaku yakni para penggali emasnya, maupun keluarga atau kerabatnya.

\section{DAFTAR PUSTAKA}

Bungin, Burhan. (2006). Analisis Data Penelitian Kualitatif. Jakarta: PT RadjaGrafindo Perkasa.

Dervin, Brenda. (1983). An Overview of Sense Making Research: Concepts, Methods and Results to Date. Paper presented at the a nnual meeting of the International Communication Association, Dallas, TX, May 10 Maret 2015 Dalam http://communication.sbs.ohiostate.edu/

Case, Donald O. (2007). Looking For Information, United Kingdom; Emerald Group Publishing Limited.

Kuswarno, Engkus. (2009). Fenomenologi: Konsepsi, pedoman dan contoh penelitian, Bandung: Widya Padjadjaran.

Moleong, Lexy J. (1989). Metode Penelitian Kualitatif. Bandung: Remadja Rosda Karya.

Nasution, S. (1988). Metode Penelitian Naturalistik Kualitatif. Bandung: Tarsito.

Pendit, Putu Laxman. (1992). Makna Informasi:

Lanjutan Dari Sebuah Perdebatan Dalam Kepustakawanan Indonesia: Potensi dan Tantangan. Jakarta: Kesainc Blanc.

Pendit, Putu Laxman. (2009). Perilaku Informasi, Semesta Pengetahuan, Artikel, dalam Putubuku.

Widodo, dkk. (2010). Pemanfaatan tailing Pengolahan Biji Emas Cara Amalgamasi Untuk Bata Cetak, LIPI. 
Wilson, T.D. (1999), Models in information behaviour research dalam Journal of Documentation, vol 55 no. 33, hal. 259 270.

Wilson, T.D. (2000). Recent trends in user studies: action research and qualitative methods dalam Information Research, vol. 5, no. 3 dari: http://informationr.net/ir/53paper76.html 
